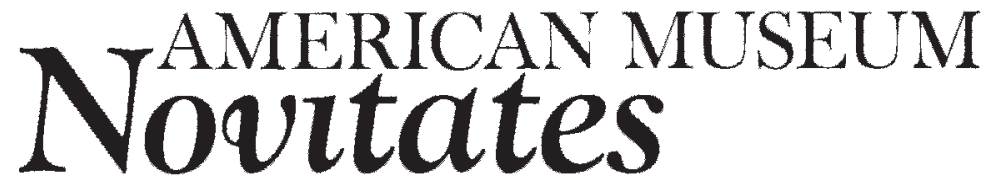

PUBLISHED BY THE AMERICAN MUSEUM OF NATURAL HISTORY CENTRAL PARK WEST AT 79TH STREET, NEW YORK, NY 10024 Number 3604, 23 pp., 10 figures, 1 table

April 9, 2008

\title{
Biology and Immature Stages of the Bee Nomioides patruelis (Halictidae: Halictinae: Nomioidini) and of Its Cleptoparasite, Chiasmognathus pashupati (Apidae: Nomadinae: Ammobatini), with a Preliminary Phylogeny of the Halictidae Based on Mature Larvae (Apoidea)
}

\author{
JEROME G. ROZEN, JR. ${ }^{1}$
}

\begin{abstract}
Mature larvae and pupae of Nomioides patruelis Cockerell and of its cleptoparasite, Chiasmognathus pashupati Engel, collected from the nesting site near Karachi, Pakistan, are described, providing the first account of the immature stages of the respective genera and the first such account for any Nomioidini. An egg of $N$. patruelis is also described.

An analysis, based on both halictid specimens and descriptions from the literature, reveals that the three subfamilies (Rophitinae, Nomiinae, and Halictinae) of Halictidae can be distinguished on the basis of their mature larvae. A key is provided for their identification. Mature larvae of the tribes of the Halictinae are so similar they cannot be distinguished at present, although studies of additional representatives may yield diagnostic features particularly concerning mandibular anatomy and perhaps body size. Features of the mature larvae when mapped onto a phylogeny of the Halictidae (Pesenko, 2000) provide a hypothesis for the sequence of anatomical changes in the evolution of mature larvae.

Observations during excavation of the nesting site provided detailed, if fragmentary, information concerning nest architecture, provisioning, voltinism, and nest parasites of Nomioides paturelis. These are discussed in relation to information concerning other species of Nomioidini from the literature.

Chiasmognathus pashupati, like its host, is probably multivoltine. The anatomy of the mature larva is similar to that of other Nomadinae, especially that of Ammobatini; however, the pupa is

\footnotetext{
${ }^{1}$ Division of Invertebrate Zoology, American Museum of Natural History (rozen@amnh.org).
} 
distinct from those of other known Ammobatini. The mature oocyte of the related C. orientanus (Warncke) from Turkey, described previously (Rozen and Özbek, 2003), is likely to resemble that of C. pashupati.

\section{INTRODUCTION}

The main purposes of this study are (1) to describe the mature larva and pupa both of the bee Nomioides patruelis Cockerell and of its cleptoparasite, Chiasmognathus pashupati Engel, and (2) to compare them with immatures of related taxa. Both species were recovered from nests at $12 \mathrm{~km}$ east of Gharo (60 km east of Karachi), Sind Province, Pakistan, on May 6-8, 1984. A short time later, I showed adults of $C$. pashupati from the site to the late Donald B. Baker, who immediately judged them to be an undescribed genus and species belonging to the Ammobatini. He retained them with the idea of describing them, but other priorities occupied his time. In 2004 Michael S. Engel retrieved the adults from the Baker collection, now housed at the University of Kansas, and named and described the species in his ongoing studies of the genus (Engel, 2007), making possible the publication of the current paper. While collecting the immatures, I was able to make brief biological observations on both $C$. pashupati and $N$. patruelis, which are included here. The descriptions of the mature larva and pupa of $N$. patruelis are the first for any Nomioidini (McGinley, 1989). Their availability prompted a survey of larval characters of the Halictidae to learn the extent to which they support our understanding of the phylogeny of the family.

\section{METHODS AND TERMINOLOGY}

Larval specimens were drawn and then decapitated. The two body parts were cleared in an aqueous solution of sodium hydroxide, stained with Chlorazol Black E until lightly colored, and placed in glycerin for examination with stereo- and compound microscopes. Pupae were studied and drawn without preliminary treatment. In the pupal descriptions, the following abbreviations are used: $\mathrm{T}=$ metasomal tergum; $\mathrm{S}=$ metasomal sternum; hence, $\mathrm{T} 1$ is the first metasomal tergum, S6 is the sixth metasomal sternum, etc.
The spiracular line referred to in larval descriptions and in the key to larvae is an imaginary line that passes through and connects the spiracles on one side of the body when the larva is viewed laterally.

After they had been critical-point dried and coated with gold/palladium the egg of $\mathrm{No}$ mioides patruelis and pupa of Chiasmognathus pashupati were examined with a Hitachi S5700 scanning electron microscope (SEM) in the Microscopy and Imaging Facility of the AMNH.

\section{NESTING BIOLOGY OF NOMIOIDES PATRUELIS COCKERELL}

A limited amount of information on nesting biology of Nomioides is available in the literature (Batra, 1966; Blüthgen, 1925; Radchenko, 1980), and nothing has been reported concerning $N$. patruelis.

Description of Nesting Site: The nests of this small species (body length approximately $3.0-4.0 \mathrm{~mm}$ ) were discovered because of the flight activity of its males and the presence of both sexes of Chiasmognathus pashupati close to the surface of nearly barren ground along the edge of a mostly horizontal, narrow, dirt roadway (fig. 1). Only three nests were discovered, all within several meters of one another, but many more nests probably occurred along the same stretch, although they presumably were absent in the center of the road and in the wheel tracks of cars and carts that occasionally passed. The soil was extremely fine, even-grained, windblown material. Its surface layer, so loose that it could be excavated with fingers, extended down several $\mathrm{cm}$ at one nest and $11 \mathrm{~cm}$ at a second nest. Time did not permit the excavation of the third nest. The lower soil layer differed only by being more consolidated and faintly moist. The source of this moisture is unclear because of the lack of rain during the springtime in the vicinity of Karachi. Two of the nest entrances were unshaded most of the day, but the third was shaded by a bush to its west. Two nests were on horizontal surfaces, another on a 20-degree sloping surface, and 


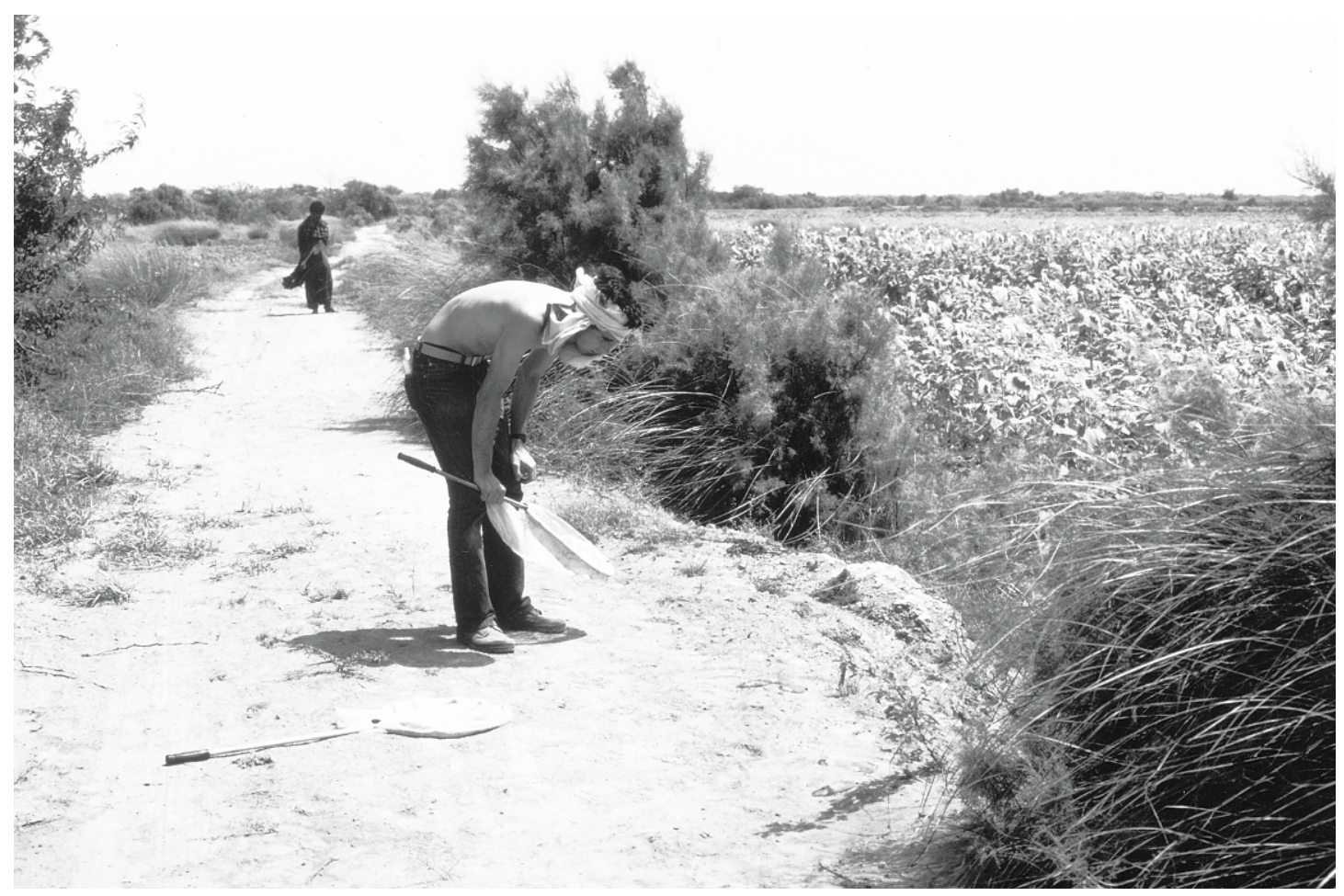

Fig. 1. Nesting site of Nomioides patruelis, 7.5 mi. east of Gharo, Sind Province, Pakistan. Ian Stuppakoff, in foreground, collecting adults flying over site.

others may have been on even steeper inclines. On the three days that we visited the site, strong, onshore winds constantly blew the fine surface material and small, dry particles of vegetation over the surface of the site. The slanting of trees as well as the shape of the branches suggested that such strong winds are typical of the region, presumably caused by daytime solar heating of the land near a cooler ocean.

Description of Nests: The two excavated nests were similar in most respects. The entrances were open despite the strong winds, and there were no tumuli. The main burrows, circular in cross-section, $1.35-1.75 \mathrm{~mm}$ in diameter, descended vertically with only slight meandering through the surface layer to the consolidated stratum, where cells occurred. Because of the small size of nest components and brevity of the field investigation, it was impossible to understand completely nest architecture. The main burrow may have branched several times in the vicinity of the cells, for several vertical and diagonal tunnels were found at that level in both nests. One of the tunnels was clearly plugged by a short septum, at most several $\mathrm{mm}$ long, and such plugging was suggested elsewhere. It is unknown whether these apparent branches were each occupied by a single provisioning female or even whether there were typically more than one female to a nest. Tunnel walls were dull and appeared unlined.

Cells ranged in depth from $13-17 \mathrm{~cm}$ in one nest and $14-20 \mathrm{~cm}$ in the other. The laterals leading to cells ranged in length from 6$10 \mathrm{~mm}$ in three cases, and some other cells appeared to be closer to the main burrow. Several cells were oriented $20^{\circ}-30^{\circ}$ from horizontal with the front end higher than the rear, and although other cells may have been somewhat more steeply tilted, all tended to be more or less horizontal rather than vertical. Because of its small size, exact cell shape was difficult to determine. The rear end was rounded and the remainder of the cell 
appeared symmetrical around its long axis, that is, the floor did not appear flat while the ceiling arched, as diagramed for example in the case of Exomalopsis (Apidae) (Rozen, 1984: figs. 16-24). Seven cells ranged in diameter from $2.2-2.5 \mathrm{~mm}$, and one was $4.5 \mathrm{~mm}$ long and two others each $4.0 \mathrm{~mm}$ long. Thus, they did not have the "fat" appearance of cells typical of the Rophitinae, where the maximum diameter is much closer to cell length (Rozen and Özbek, 2008). They were arranged singly, not in linear series.

There was no evidence of a plastered or masoned cell wall; the texture of the wall just beneath the lining was of the same appearance and hardness as the rest of the substrate. The lining, obviously applied by the female, was distinct, semitransparent, shiny, fragile, and moderately smooth (fig. 3), and it coated the entire cell wall. A droplet of water was absorbed only if the wall was accidentally punctured when the droplet was applied to the lining.

Cell closures appeared deeply concave on the inside in two cases (fig. 2). One of these, $1.5 \mathrm{~mm}$ in diameter, was a spiral of approximately three loosely consolidated coils. There was no evidence of a special outer surface to the closure as is the case with some bees; the closure seemed continuous with the fill of the lateral. All laterals to closed cells were filled with soil that was somewhat looser than the substrate.

The two nests contained numerous cells, both occupied and already vacated. As emerging bees departed through the laterals, they backfilled cells with loose soil, but the cells could easily be identified as belonging to bees by clusters of orange fecal pellets lining the rear walls of cells (fig. 3).

In general, nest architecture of this species appears to be consistent with that described for the nests of a number of species of Nomioides by Batra (1966), and as also reported by Radchenko (1980) for the nests of N. minutissimus (Rossi).

Provisioning: Several cells of the first nest excavated were recently provisioned with orange pollen from an unknown plant. I was unable to identify the pollen source or even females carrying pollen, perhaps because most of my observations were made in the after-

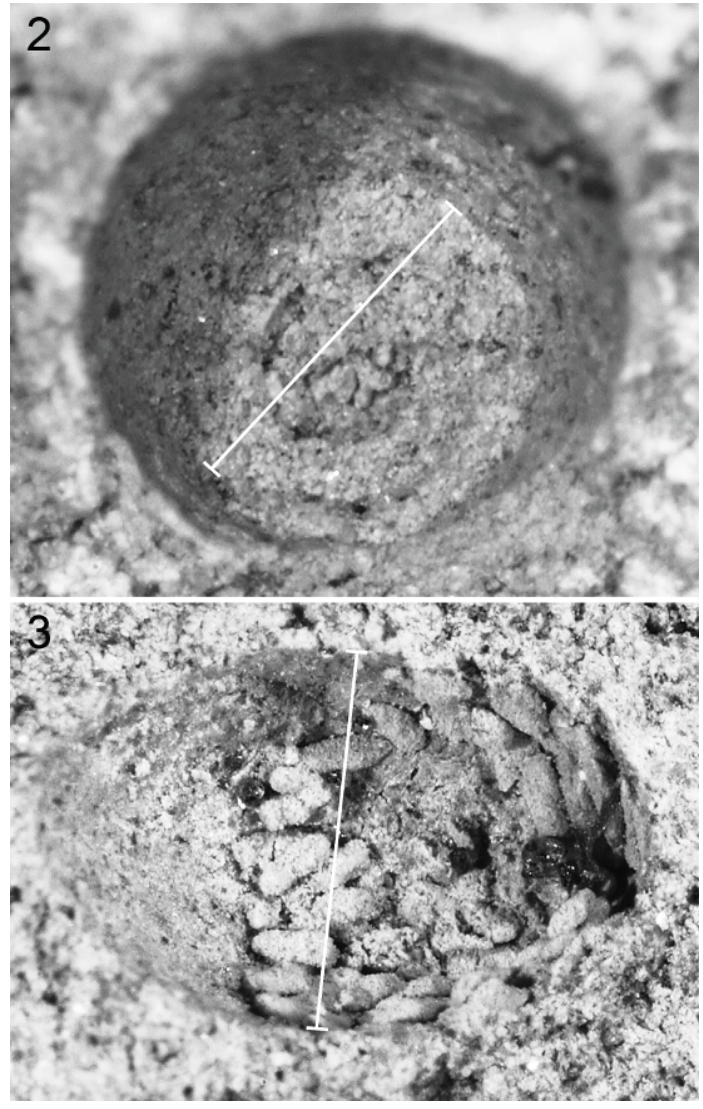

Figs. 2, 3. Brood cells of Nomioides patruelis. 2. Front end of cell, inner view, showing deeply concave spiral cell closure; line demarking closure diameter $=1.5 \mathrm{~mm}$. 3. Approximate longitudinal view with front end at left. Note slight shine of lining on cell wall at left and feces piled on wall at rear end of cell; line demarking cell diameter $=\mathrm{ca}$. $2.5 \mathrm{~mm}$.

noon whereas provisioning may take place mostly in the morning. Females shaped stored provisions into spheres with flattened tops and bottoms, each with the upper surface distinctly flatter than the lower one. They were mealy moist throughout, not covered with a waterproof coating (as is the case with some Dufourea [Rozen and Özbek, 2008]). Three provision masses measured $1.8-2.0 \mathrm{~mm}$ in maximum diameter and $1.4-1.5 \mathrm{~mm}$ in height. The provisions are presumably oriented with the flatter surface facing upward as was judged by a curved egg that was found 
attached to that surface (but food orientation needs further study).

Batra (1966) reported that some species of Nomioides had spherical provision masses and others had flattened spheres. Radchenko (1980) stated that the provisions of Nomioides minutissimus are "spherical and slightly flattened at the poles."

Development and Egg Description: The single egg (fig. 5) found was strongly curved, elongate, white, with a shiny chorion. Broadly rounded at the front end, it was $1.1 \mathrm{~mm}$ long, with a maximum diameter of $0.24 \mathrm{~mm}$, just behind its front end. It gradually tapered posteriorly toward the posterior end, which was narrowly rounded. SEM examination revealed no chorionic patterning except at the anterior pole where the micropyle consisted of a tight cluster of pores with angled borders (figs. 10, 11). The anterior and posterior ends of the egg rested on the top of the provisions, and the rest of the egg arched upward so that it did not contact the food mass. Several partly grown larvae fed actively on the food beneath the anterior part of their bodies, so that the front ends of the food masses were consumed while the rear parts of the masses remained as originally formed. This indicates that the larva is sedentary, feeding on the provisions beneath its head, at least during early development. This behavior is contrary to that of at least some Rophitinae (Torchio et al., 1967), where the larva crawls over the food as it feeds. Several mature larvae were discovered: one predefecating form and several postdefecating forms. All were active, and the postdefecating forms were approaching pupation, as determined by the shape of their bodies and the appearance of the pupa through the larval integument when they were preserved. The absence of diapausing larvae and the presence of active postdefecating forms and developing pupae indicate that the nesting population was not entering a diapausing period; thus, the population was multivoltine. Feces were applied as slightly flattened orange pellets over the entire surface of the rear half of the cell. No nomioidine is known to spin a cocoon; in the Halictidae, cocoon spinning is restricted to the Rophitinae and is lost in that subfamily only in Conanthalictus (and questionably Xeralictus) (Rozen and Özbek, 2008).

Adult Activity: Large numbers of adults, mostly males, were first seen as they flew in a zigzag fashion over the ground and around the stems of low-growing plants next to the road. The swarming, rapidly fluttering, zigzag flight of tiny bees mirrored the same behavior of the unrelated but similar appearing bees of the genus Perdita (Andrenidae) in North America. Adults, apparently mostly males, landed briefly on plant stems only to depart moments later. I do not know the function of the swarming flight and observed no mating, although my observations were brief. Other males, few in number, were observed flying swiftly very close to the ground as if in search of females or places to spend the night.

Nest Associates: In addition to Chiasmognathus pashupati definitely associated with the nests of this species, a large mite was found seemingly engorging itself on the still active larva of Nomioides patruelis, which was in the process of defecating. Pavel Klimov (personal commun.) identified it as an "adult female of Anoetus (family Histiostomatidae) filled with numerous eggs." A number of moderately large reddish mites identified by Klimov as Tarsotomus hercules Berlese (Anystidae) crawled rapidly over the nesting site.

\section{BIOLOGY OF CHIASMOGNATHUS PASHUPATI ENGEL}

Adults of Chiasmognathus pashupati, about the same size as their hosts, flew very close to the surface at the nesting area. Because both sexes were collected, they presumably mate there. The flight of the male was swift, and although it did not zigzag with as much flutter as that of the host males, there were sufficient similarities that one could not always distinguish between them in flight. Female $C$. pashupati flew slightly more slowly and seemed to be searching for nest entrances, although I saw only one female actually descend into a nest.

One postdefecating larva and one pupa were recovered from cells. The fecal pellets in these cells were thinner than those of the host and were found at both the rear and front ends of the cell, but not in between. Thus, cells 
containing postdefecating immature stages of the cleptoparasite could be distinguished from those of the host, which had feces only at the rear of the cell.

A small circular hole in the rear wall of the cell containing the pupa of Chiasmognathus pashupati was probably the oviposition site from which the individual had emerged. No flap of cell wall was visible. The presence of an active, developing, postdefecating larva, several pupae, and an emerging male suggests that, like its host, this species is multivoltine.

No egg or mature oocyte of Chiasmognathus pashupati was available for examination. However, mature oocytes from two specimens of the related $C$. orientanus (Warncke) from Turkey were described by Rozen and Özbek (2003) under the name of "Parammobatodes" orientana (Warncke). Almost certainly, when the deposited egg of this species or of $C$. pashupati is found in situ, the operculum will be found approximately flush with the cellwall surfaces, while the rest of the egg will be buried in the wall and its posterior part will be folded under the anterior part, as illustrated for Pasites maculatus Jurine by Rozen (1986: fig. 6). The egg of $C$. pashupati will probably be slightly smaller than that of $C$. orientanus since the average intertegular distance (distance between outer rims of tegulae) of the latter is $0.99 \mathrm{~mm}$ compared with the average intertegular distance of five females of $C$. pashupati of $0.82 \mathrm{~mm}$. Considering the similarities in the egg/mature oocytes and egg/ ovarian statistics among the Ammobatini as reported by Rozen and Özbek (2003), we can anticipate close agreement in these matters between $C$. orientanus and $C$. pashupati.

\section{MATURE LARVAE AND PHYLOGENY OF HALICTIDAE}

With information about a larval exemplar of the Nomioidini now available, it is perhaps worthwhile to analyze the extent to which larval characters of the family fit our understanding of the phylogeny of the family as determined by Pesenko (2000), whose study was a revision of an analysis by Alexander and Michener (1995) based on adult anatomy. The larval characters are derived from two sources: (1) descriptions in the literature and (2) firsthand examination of larval specimens. The following are the literature references: ROPHITINAE: Rozen and Özbek (2008); NOMIINAE: Michener (1953) and Hirashima (1961); HALICTINI and AUGOCHLORINI: Eickwort (1979), Eickwort and Eickwort (1972a, 1972b, 1973), Michener (1953), Rozen (1965), and Torchio (1975); NOMIOIDINI: current study. In addition, I have examined specimens from the collections of the University of Kansas (on long-term loan), the University of California, Berkeley (also on long-term loan), and the Smithsonian Institution (on short-term loan), as well as from the American Museum of Natural History. The larval descriptions from the literature and examined specimens are exemplars of the following genera: ROPHITINAE: Conanthalictus, Dufourea, Protodufourea, Rophites, Sphecodosoma, Systropha, Xeralictus; NOMIINAE: Dieunomia, Nomia, Pseudapis; HALICTINI: Agapostemon, $\mathrm{Ha}-$ lictus, Lasioglossum, Microsphecodes, Sphecodes; AUGOCHOLORINI Augochlora, Augochlorella, Corynura, Neocorynura; NOMIOIDINI: Nomioides. Because only 20 genera of Halictidae of a possible total of 75 (Michener, 2000) are represented, this analysis is preliminary, but it is the first such treatment of the mature larvae of the family since Michener (1953) published his comprehensive study of bee larvae.

Table 1 gives a comparison of larval characters of the higher taxa of Halictidae, and the characters are further explained here. Not all those identified proved of value to the current analysis but are discussed because their variability may be useful at some level after more exemplars become available.

MANDIBUlar APEX: With the examination of numerous species, both the Nomiinae and Halictinae show considerable diversity as to whether the mandible tapers to a single point or is bidentate with the two subequal apical teeth. Thus, this feature seems of little value in interpreting relationships among the subfamilies.

POSITION OF ANTERIOR TENTORIAL PIT RELATIVE TO THAT OF THE ANTERIOR MANDIBULAR ARTICULATION: In the Rophitinae, the anterior tentorial pit is close to the anterior mandibular articulation, so that the lateral segment of the epistomal ridge (i.e., the length of the ridge from the pit to the articulation on 


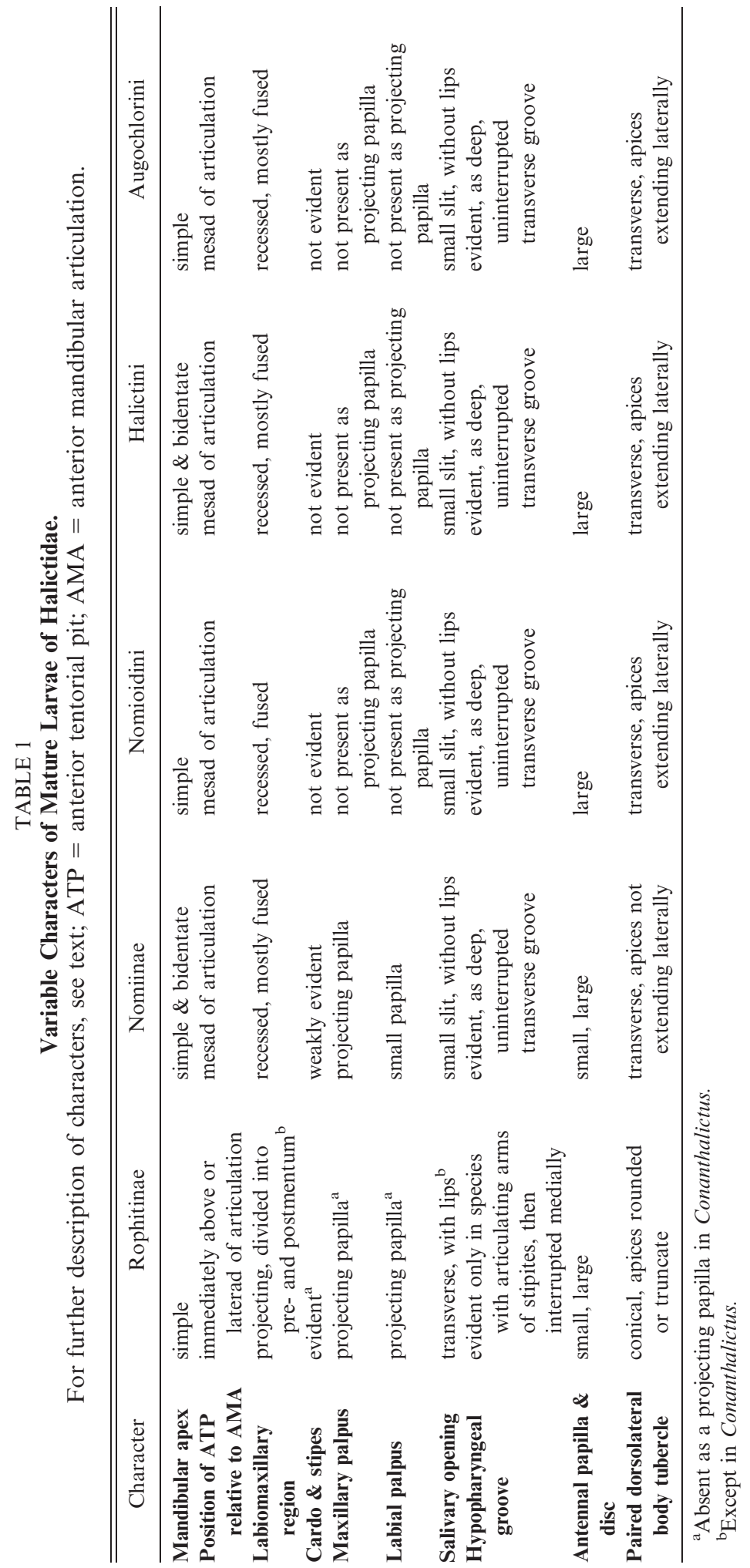


the same side of the head) is very short whereas the distance between the two anterior tentorial pits is extensive. Because the pit is so close to the articulation, it is immediately above it or even above and laterad of it. In other halictids, the pit is much farther removed from the articulation, making the lateral segment of the epistomal ridge longer while the two anterior pits are much closer together. Since the anterior tentorial pit is close to the anterior mandibular articulation in the larvae of most of the families of shorttongued bees, this feature is considered plesiomorphic, whereas the pit farther removed from and mesad of the pit (i.e., long lateral section to the epistomal sulcus) is apomorphic.

LABIOMAXILLARY REGION：Cocoon-spinning bee larvae invariably share certain anatomical features: the labiomaxillary region projects forward, the prementum and postmentum are elongate with the prementum extending from and retracting into the postmentum during cocoon spinning, and the salivary lips are transverse and project (all of these adapted for applying silk during cocoon construction). Except for those of Conanthalictus (and perhaps Xeralictus ${ }^{2}$ ), mature rophitine larvae spin cocoons; no other halictid larvae do so. Cocoon spinning in bees and in other Hymenoptera is widespread and, no doubt, plesiomorphic. It is highly unlikely that a bee lineage, after it has lost the anatomical structures and necessary behavioral traits for spinning, will regain them. Thus, under such a scenario cocoon spinning has been lost twice in the Halictidae (excluding Xeralictus from consideration).

Non-cocoon-spinning bee larvae also share certain features. In addition to not having projecting salivary lips, the labiomaxillary region tends to be recessed as seen in lateral profile, and often the divisions between the prementum and postmentum becomes weak or even absent. Other features are discussed below.

CARDO AND STIPES: Cocoon-spinning larvae have sclerotized (but not necessarily pigmented) cardines and stipites, no doubt because such structures are involved with the labio-

\footnotetext{
${ }^{2}$ Snelling and Stage (1995: 5) were uncertain "whether or not Xeralictus spins a pupal cocoon".
}

maxillary musculature required for cocoon spinning. In the Halictidae, these structures are found only in the Rophitinae and are plesiomorphic. It is not surprising, therefore, that these structures are lost in Conanthalictus as well as in all other non-cocoon-spinning halictids. Interestingly, the articulating arm of the stipes has not been lost with the other maxillary sclerites in the non-cocoon spinners; it is clearly present on each side of the head in larger specimens (and apparently also in smaller specimens). The pair are directed toward one another in the recessed hypopharyngeal groove and appear to fuse at the midline, thus giving rise to an uninterrupted, transverse hypopharyngeal groove, discussed below. The loss of the articulating arms in Dufourea and Sphecodosoma, both cocoon spinners, is inexplicable at present; the loss in Conanthalictus results perhaps from the loss of cocoon spinning in that lineage.

MaXillary Palpus: This structure on most bee larvae is a projecting, cylindrical papillalike tubercle bearing a number of apical sensilla, as in the Rophitinae and Nomiinae. It is thus plesiomorphic, and the loss of a tuberculate palpus in the Halictinae is apomorphic.

LABIAL PALPUS: This palpus is similar to the maxillary palpus except it is extremely small in the Nomiinae as well as completely absent as a papillalike tubercle in all Halictinae (an apomorphic condition). Although the palpus is no longer projecting in any of the halictine tribes (as identified by Michener, 2000), a small cluster of sensilla somewhat below and laterad of the salivary opening on each side of the labial apex is presumably a remnant of the palpus.

SALIVARY OPENING: As mentioned under "Labiomaxillary Region", above, all rophitines spin cocoons except for Conanthalictus. The existence of all cocoon-spinning structures, including projecting transverse salivary lips, of these bees are considered plesiomorphic.

Hypopharyngeal gRoOve: Among cocoon-spinning mature bee larvae, the hypopharynx is the median, usually lobelike structure that is located just below the true mouth. Distal to it is the labial prementum, which articulates with it. In bee larvae in 
which the premental sclerite is heavily sclerotized (e.g., Bombus, Apis [Apidae]), a tapering mesal spur of each maxilla, called the articulating arm of the stipes, comes diagonally forward and, at its apex, articulates with the upper side of the premental sclerite (Rozen and Michener, 1988). The hypopharyngeal groove in this situation is the transverse line created by the basal boundary of the premental sclerite, which abuts the hypopharynx.

With many cocoon-spinning bee larvae, the premental sclerite is far less sclerotized than that of Bombus or Apis. For example, in Exaerete (Apidae) (Garófalo and Rozen, 2001), the dorsolateral part of the premental sclerite on each side is pigmented and sclerotized, but the dorsal sclerotization accompanied by pigmentation is completely interrupted medially and the pigmentation gradually fades completely laterally on each side. The articulating arms of the stipites are pointed diagonally toward the two most darkly pigmented areas just laterad of the median interruption. In cases such as this, the hypopharyngeal boundary medially can be considered to be an imaginary line extending either between the posterior margins of the two lateral remnants of the premental sclerite or between the apices of the articulating arms of the stipites. Among other cocoon-spinning bees with limited sclerotization of the prementum, the integument is folded transversely at the boundary making a more or less conspicuous line, unaccompanied by sclerotization.

In the known Rophitinae the premental sclerite is absent or so weakly defined that its posterior boundary is unrecognizable. Among those that spin cocoons (all except Conanthalictus), the hypopharyngeal groove is an imaginary line extending between the apices of the articulating arms of the stipites though there is not even a fold in the integument between these points. In the rophitine genera in which the arms are absent (Dufourea and Sphecodosoma), there is no way to determine the precise position of the supposed hypopharyngeal/premental boundary. The absence of a visible hypopharyngeal groove in the Rophitinae is presumably apomorphic, but only because there is no visible premental sclerite. Otherwise, the re- maining structure of the labiomaxillary region is considered plesiomorphic by virtue of the fact that cocoon spinning is plesiomorphic. The absence of the articulating arm of the stipes in two genera is derived from the condition found among the other rophitine genera.

The Nomiinae and Halictinae differ from the Rophitinae in that their mature larvae do not spin cocoons and the labiomaxillary region is significantly modified. This composite structure is generally less elongate, and the articulating arms of the stipites curve mesad so that they point to one another. Extremely thin, they are embedded in a narrow trough that now forms an uninterrupted transverse hypopharyngeal groove, whose composition is best seen on large specimens. With some if not all taxa, the two arms seem either to fuse medially just above the salivary opening or to be linked medially by an equally thin sclerite, perhaps a remnant of the premental sclerite. This situation is obviously apomorphic since it is associated with non-cocoon spinning.

ANTENNAL PAPILLA AND DISC: In larval Halictinae the antennal disc is large and the papilla is also large at the base while its differentiation from the disc is somewhat obscure. This situation is similar to that of Conanthalictus and Sphecodosoma in the Rophitinae, some Nomiinae. Furthermore, there exists variation in the size of the character, so that its interpretation is problematic. Nonetheless, small size in the diameter of the disc appears to be the usual situation among other families of shorttongued bees, so that condition is possibly plesiomorphic.

Paired dorsolateral BOdy TUberCles: The paired dorsolateral body tubercles of the Rophitinae are conical, not transverse, with apices that are rounded or truncate and with the prothoracic tubercles either somewhat smaller than those of the succeeding segments (most genera) or totally absent (Conanthalictus). In the Nomiinae, they are transverse in that each tubercle is much broader than its front-to-back dimension, but from the limited sampling of taxa, they seem less extremely transverse than those of the Halictinae. In the Halictinae, they are extremely transverse to the degree that they extend down the sides of 


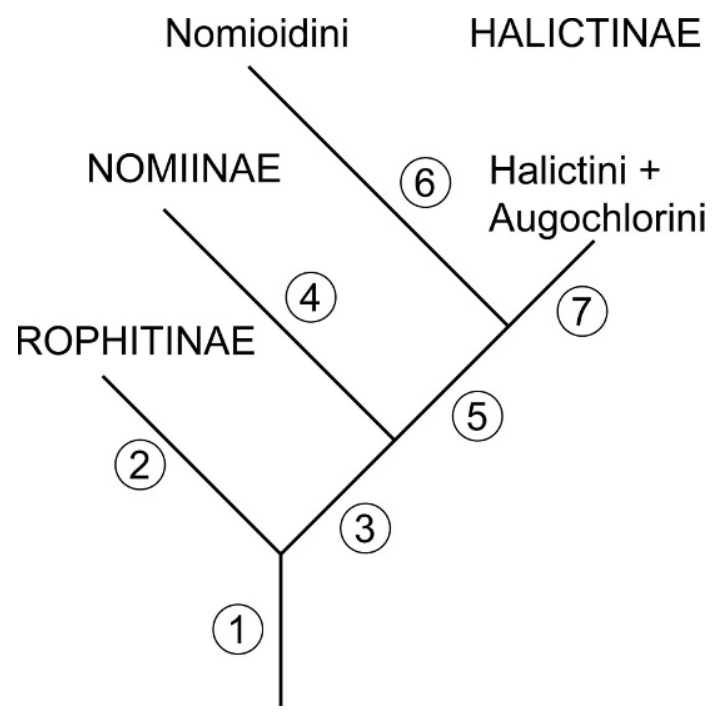

Fig. 4. Cladogram, modified from a cladistic analysis by Pesenko (2000: fig. 1), maps phylogenetic events in the evolution of the mature larvae of the Halictidae: (1) Ancestral features: mandibular apex simple; anterior tentorial pit immediately above or laterad to anterior mandibular articulation; labiomaxillary region projecting, well divided into pre- and postmentum; cardo and stipes evident; maxillary and labial palpi projecting papillae; salivary opening transverse, with projecting lips; hypopharyngeal groove probably indicated either by apices of articulating arms of stipites or by posterior margin of premental sclerite if present; paired dorsolateral body tubercles present or absent but, if absent, then most abdominal segments divided into cephalic and caudal annulets; larvae cocoon spinners. (2) Rophitine lineage similar to ancestral ground plan except paired conical dorsolateral body tubercles, if not present in ancestor, now present on most caudal annulets of abdominal segments. Within that lineage (a) cocoon spinning ceased in one place (Conanthalictus) and larval characters associated with cocoon spinning lost and (b) articulating arm of stipes lost presumably more than once (Dufourea, Sphecodosoma, and Conanthalictus). (3) Anterior tentorial pit shifted mesad, so that lateral segment of epistomal ridge lengthened; labiomaxillary region recessed, and preand postmentum partly fused; cardo and stipes fading but still weakly evident; labial palpus reduced but evident as small papilla; salivary opening without lips; hypopharyngeal groove complete, consisting of narrow furrow with embedded articulating arms, which are slender and curving toward one another; paired transverse dorsolateral body tubercles, if not present in ancestor, present on caudal annulet of most abdominal segments; the body segment and end only as they approach the level of the spiracles in lateral view.

From table 1, we see that there are no known larval features by which the tribes of the Halictinae can be distinguished from one another. Nomioidini, as represented by Nomioides patruelis, fits well within the larval features of the subfamily. Similarly such features (Eickwort and Eickwort, 1972b; Michener, 1953; Rozen, 1965, Torchio, 1975) of the cleptoparasitic subtribe Sphecodina of Pesenko (2000) are not distinguishable from other Halictinae. ${ }^{3}$

When the features of the mature larvae of the Halictidae are analyzed in relation to our current understanding of the phylogeny of the taxa within the family, we can consider the sequence of steps that took place in the evolution of these features. Figure 4 is a cladogram modified from that of Pesenko's (2000) study of the adults, and the explanation of the figure details the sequence of probable evolutionary changes in the mature larvae of the family.

\footnotetext{
${ }^{3}$ Interestingly, a postdefecating larva and pupa collected by Claude-Joseph with adults of Ruizantheda mutabilis (= Halictus mutabilis) had with them a single adult Sphecodes, similar in coloration and only slightly smaller than the adult $R$. mutabilis. This and the fact that ClaudeJoseph (1926) does not mention Sphecodes suggest that he may have either been unaware of the identity of the specimen or assumed that it was not a parasite of $R$. mutabilis. Unfortunately, this does raise the question of the true identity of the immature stages, since we do not know how to distinguish larvae or pupae of the Halictinae at the subtribal level.
}

ability to spin cocoons lost. (4) No other larval apomorphies identified. (5) Cardo and stipes no longer evident; maxillary palpus not evident as papilla; paired dorsal body tubercles not only transverse but also extending laterally almost to level of spiracular line. (6) Pre- and postmentum completely fused (may be due to very small size). (7) No other apomorphies identified. 


\section{PRELIMINARY KEY TO SUBFAMILIES OF HALICTIDAE BASED ON MATURE LARVAE}

The above analysis provides characters for the following key.

1. Labiomaxillary region strongly projecting; labium clearly divided into postmentum and prementum; salivary opening transverse, surrounded by projecting lips; larva cocoon-spinning; paired dorsolateral body tubercles conical with apices rounded to truncate ... Rophitinae (part), most genera

- Labiomaxillary region undivided or only weakly divided into postmentum and prementum; salivary opening usually small, circular, and never surrounded by projecting lips; larva non-cocoon spinning; paired dorsolateral body tubercles rounded or transverse, never truncate ................. 2

2(1). Paired dorsolateral tubercles present on prothorax and most other body segments; postdefecating larvae variable in size; paired dorsolateral body tubercles transverse, usually strongly so . . . . . . . . . . 3

- Paired dorsolateral tubercles absent on prothorax, present on most other body segments; postdefecating larva very small; paired dorsolateral body tubercles rounded, never transverse . . . . . . . . . . .

.......Rophitinae (part), Conanthalictus

3(2). Labial palpus small but projecting as papilla . . . . . . . . . . . . . . . . Nomiinae

- Labial palpus not projecting, non-papillalike, represented only by sensilla ... Halictinae

\section{POSTDEFECATING LARVA OF NOMIOIDES PATRUELIS}

\section{Figures 6-9}

DiAgnosis: Characters of mature larvae that might prove useful in separating species within the tribe and members of one halictine tribe compared with another are: (1) body size and (2) mandibular morphology, especially mandibular apex (whether simple or bifid), arrangement of mandibular teeth, extent of cusp expression, and perhaps extent of development of apical concavity and of development of setiferous tubercles on outer mandibular surface. Noteworthy is the fact that the ventral apical edge of the mandible of Nomioides paturelis lacks teeth (fig. 9), con- trary to the conditions found in other known Halictinae.

DESCRIPTION: Length approximately 3.2 mm. Head (figs. 7, 8): Integument of head capsule with scattered, inconspicuous, nonsetiform sensilla; spicules absent except epipharyngeal surface and dorsolateral surface of mandibles with conspicuous spicules. Integument unpigmented except for mandibular apices.

Head (fig. 6) moderate in size compared with body; head capsule much wider than length measured from top of vertex to lower clypeal margin in frontal view. Tentorium possibly complete but specimen nearing ecdysis. Anterior tentorial pit well removed from anterior mandibular articulation (fig. 7) and well mesad of imaginary vertical line drawn through pit paralleling median line of head; posterior tentorial pit in normal position; postoccipital ridge thin but pronounced, except fading completely near median line; median longitudinal thickening of head capsule absent; hypostomal ridge thin but pronounced, its posterior section giving rise to short ramus curving to connect with postoccipital ridge (not visible in lateral view, fig. 8); pleurostomal ridge thin but pronounced; epistomal ridge laterad of (below) anterior tentorial pit thin, moderately pronounced, moderately long; ridge between pits absent. Parietal band not evident. Antennal prominence large, projecting; antennal disc very large; papilla large, scarcely differentiated from disc, strongly projecting, although its height about one-half basal diameter of disc, its apex subacute, each bearing 2-3 sensilla (fig. 7). Vertex with strongly projecting mound on each side as seen in frontal view (fig. 7). Labrum projecting somewhat farther than clypeus in lateral view (fig. 8) because of low, paired, apical labral tubercles, moderately short in frontal view (fig. 7); anterior edge of epipharyngeal surface spiculate.

Mandible (too small to be dissected from head but interpreted through cleared head capsule) in adoral view (fig. 9) narrowing rather abruptly so that apical one-third to one-half tapering to apex; dorsal apical edge with sharp, apically directed teeth; ventral apical edge without teeth; cusp weakly produced in dorsal and ventral views, with 
5
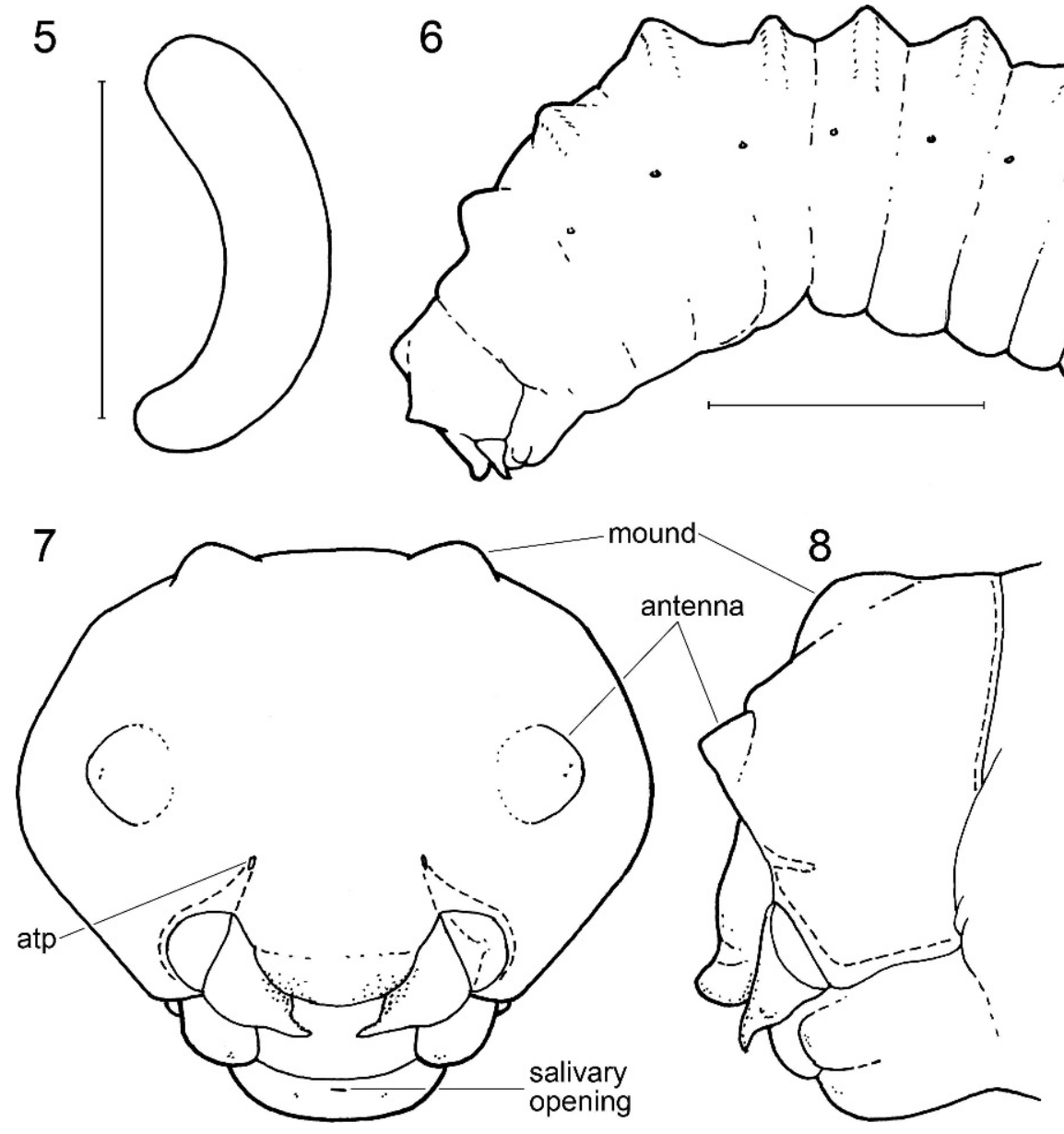

9

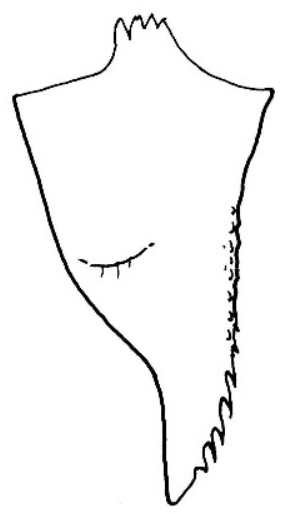

Figs. 5-9. Immatures of Nomioides patruelis. 5. Egg, lateral view, anterior end at top. 6. Postdefecating larva, lateral view. 7, 8. Head, frontal and lateral views, respectively. 9. Right mandible, outer surface. Scales $(=1.0 \mathrm{~mm})$ refer to figs. 5 and 6 , respectively. Atp $=$ anterior tentorial pit.

number of sharply pointed, apically directed teeth, similar to teeth of dorsal apical edge; apical concavity apparently not developed; outer mandibular surface with three or four weak tubercles; much of dorsal surface proximal to apex with numerous, evenly placed denticles; ventral surface without denticles. Labiomaxillary region small, recessed in lateral view (fig. 8), with apex of maxilla projecting about as far as apex of labium, but both structures behind apex of hypopharynx. Maxillary sclerites (cardo, stipes) not evident; articulating arm of stipital sclerite not evident (but see explanation of "Hypopharyngeal groove" in "Mature Larvae and Phylogeny of Halictidae"; maxillary palpus absent as papilla, but sensilla apparently present. Labium not divided into prementum and postmentum, premental sclerite not evident; labial palpus as papilla not present. Salivary opening a small slitlike hole, without lips, below hypopharyngeal groove. Hypopharynx protuberant, lobelike, nonspiculate; hypopharyngeal groove distinct (despite apparent absence of articulate arm of stipital sclerite).

Body: Integument with fine, scattered, nonsetiform sensilla and without spicules except apices of dorsolateral tubercles as described below. Body form (fig. 6) moderately robust; intersegmental lines, particularly of thorax, weakly incised because of expansion of pupal 

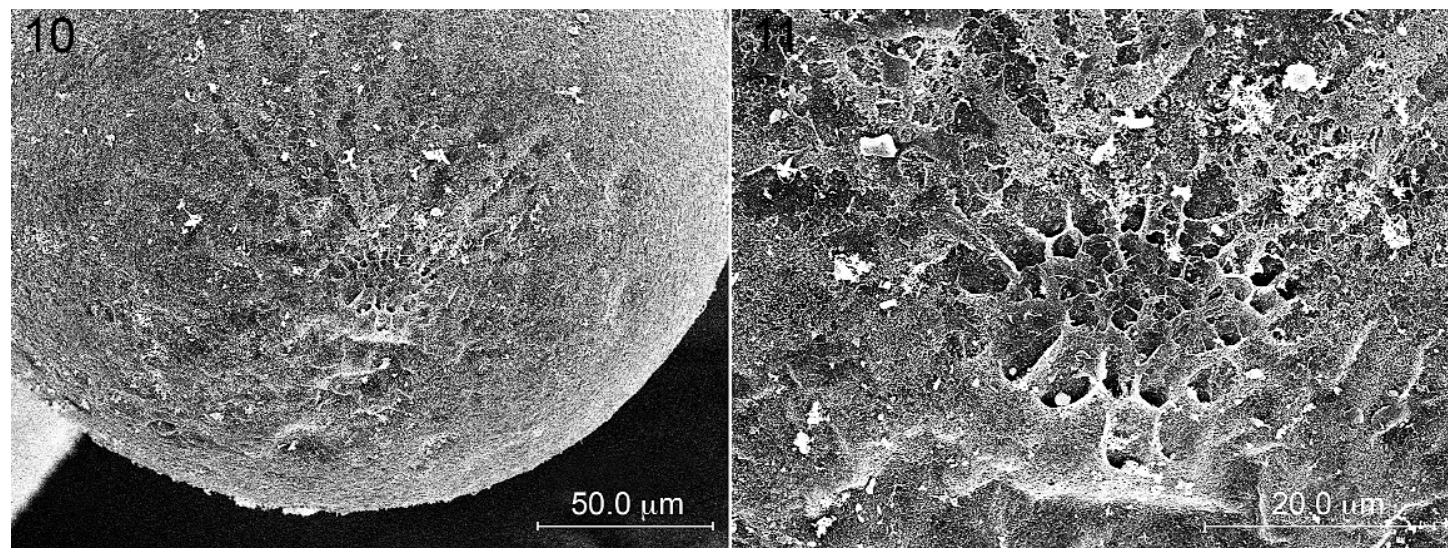

Figs. 10, 11. SEM micrographs of anterior end of egg of Nomioides patruelis and close-up of micropyle, respectively.

thorax; intersegmental lines of abdomen deeply incised, this effect accentuated by lateral extensions of paired dorsolateral tubercles; paired dorsolateral tubercles subequal in size, present on all thoracic segments; paired dorsolateral tubercles of first abdominal segment apparently smaller than those of thorax and of immediate following abdominal segments but this possibly an artifact created by developing pupal shape; dorsolateral tubercles of abdominal segments 6-9 becoming progressively smaller; summits of all paired dorsolateral body tubercles (but especially those of abdomen) weakly but clearly transverse (not conical) so that tubercle summit extending from shortly above spiracular line nearly to larva's midline, its integument somewhat thicker (more heavily sclerotized?) (as evidence by slightly darker stain from Chlorazol Black E) and spiculate, thus creating series of transverse spiculate ridges along larva's dorsolateral and dorsal surfaces, with each ridge interrupted along body midline; abdominal segment 10 without distinct paired dorsolateral tubercles but posterior dorsolateral surface somewhat elevated; abdominal segment 9 scarcely if at all produced ventrally; abdominal segment 10 positioned approximately centrally on 9 as seen in lateral view (fig. 6). Anus position slightly dorsally on abdominal segment 10 as seen in lateral view (fig. 6). Spiracles very small, subequal in size, not on tubercles; peritreme present; atrium apparently not projecting beyond wall, questionably with rim, globose; atrial wall smooth; primary tracheal opening questionably with collar; subatrium slender, normal in length, multichambered. Sex characters unknown.

Material Studied: Two postdefecating larvae, Pakistan: Sind Province: Gharo, 38 mi E of Karachi, May 8, 1984 (J.G. Rozen, S. Lodhi, I. Stupakoff).

\section{PUPA OF NOMIOIDES PATRUELIS}

Figures 17, 18, 21-26

Diagnosis: The reader is referred Rozen and Özbek (2008), where the pupa of this species was compared in some detail with other known halictid pupae. Although pupae of all Halictinae possess a conspicuous tubercle partway down on the outer surface of the forewing pad, this tubercle in Nomioides patruelis is much closer to the wing base than in other known pupae and thus is not certainly homologous with the others.

The pupa of Nomioides patruelis can easily be distinguished from that of its cleptoparasite, Chiasmognathus pashupati, because the host has limited integumental spiculation and lacks a pair of long, erect, spiculate, hornlike tubercles arising from the vertex. In addition, there are obvious differences in the dorsal mesosomal tubercles between host and cleptoparasite.

HEAD: Integument without setae, spiculate as described below. Outer surface of scape 

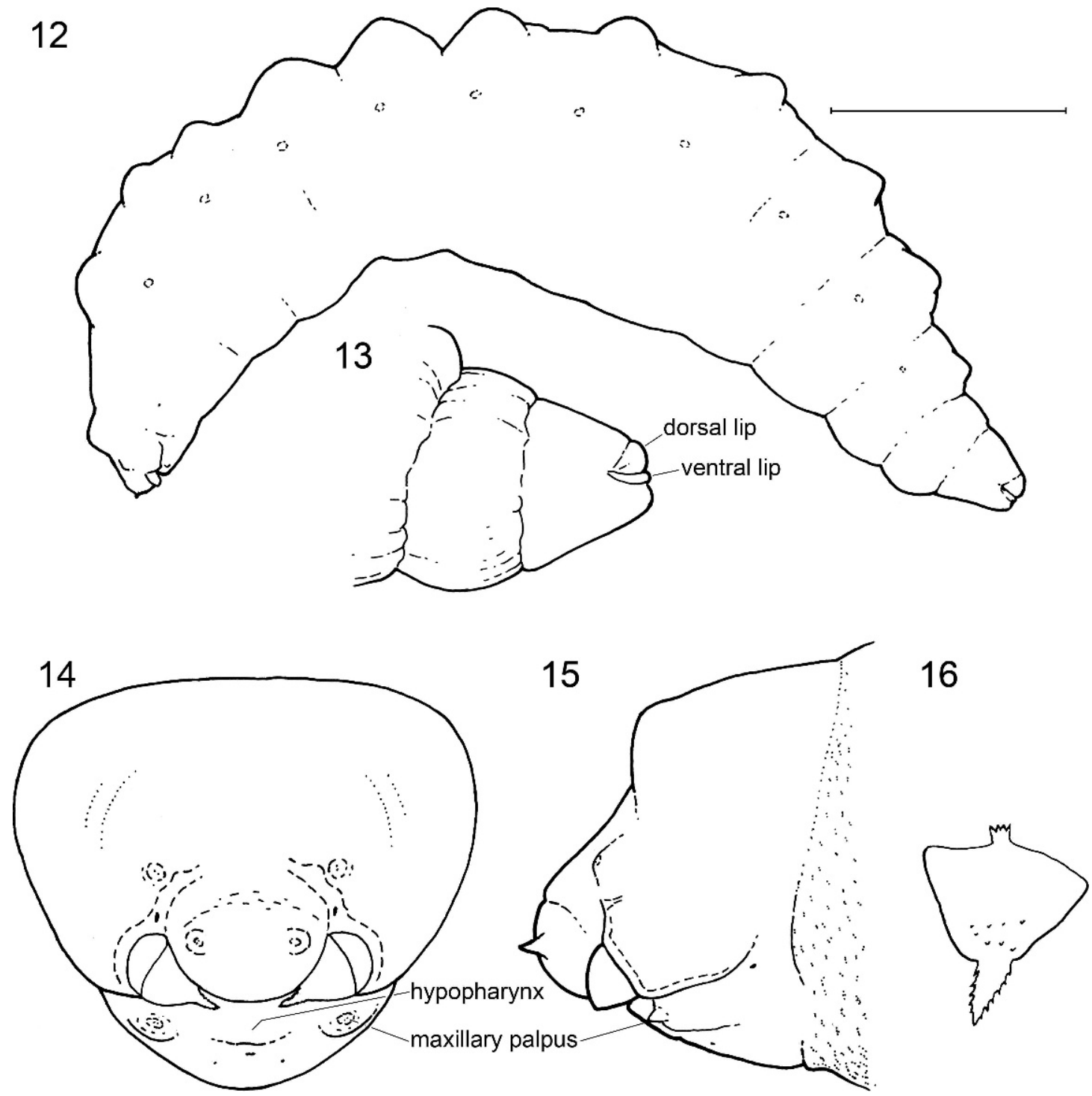

Figs. 12-16. Postdefecating larva Chiasmognathus pashupati. 12. Entire larva, lateral view. 13. Apex of abdomen, lateral view 14, 15. Head, frontal and lateral views, respectively. 16. Right mandible outer, surface.

bearing several low indistinct swellings but no distinct tubercles; inner surface (next to compound eye) of scape of female (but not male) with tubercle with indistinct apical tubercle; outer surface of pedicle of female (but not male) with tubercle; inner surface of pedicle of female (but not male) with tubercle; first flagellomere of male (but not female) with pronounced tubercle on outer surface; flagellum of male about 1.5 times longer than that of female (as in adults); flagellomeres of male tending to have more pronounced tuberclelike swellings on outer surface than those of female. Vertex spiculate near midline, with moderately large rounded tubercle immediately mesad of each adult lateral ocellus; each adult ocellus covered with small, low, rounded convexity; two more smaller rounded tubercles immediately laterad of lateral adult ocellus; upper frons with large (largest on head) lateral tubercles on each side, with less pronounced tubercle-like swelling immediately 


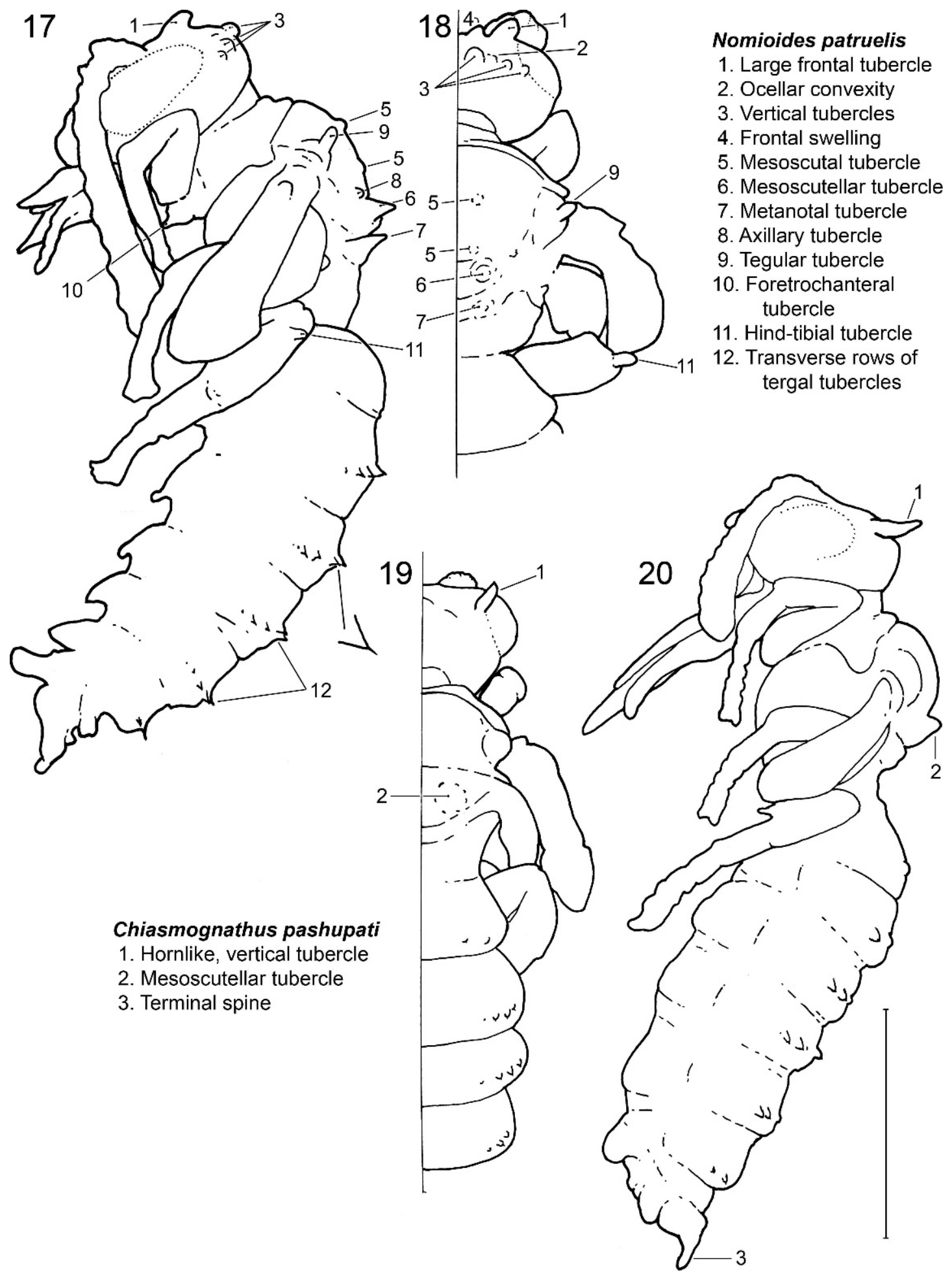

Figs. 17-20. 17, 18. Diagrams of pupa of Nomioides patruelis, lateral view, entire pupa (with tergal tubercle enlargement), and front end of pupa, dorsal view, respectively. 19, 20. Diagrams of front end of pupa of Chiasmognathus pashupati, dorsal view, and of entire pupa, lateral view, respectively. Scale (= $1.0 \mathrm{~mm}$ ) refers to all figures. 
mesad of each; genal tubercle below eye apparently absent; clypeus without tubercles; labrum of male unmodified, of female with rounded, median apical tubercle; galea spiculate, with apical tubercle (presumably accommodating developing adult setae); maxillary palpi spiculate.

Mesosoma: Integument without setae, spiculate as described below. Posterior margin of pronotum and lateral lobe swollen; mesoscutum (figs. 17, 18, 23) with pair of small, rounded paramedian tubercles medially and another, even lower pair of paramedian tubercles close to posterior margin; axilla produced as small erect tubercle (figs. 17, 24); mesoscutellum (figs. 17, 18, 24) with pair of large, strongly produced, erect, apically tapering, acutely rounded, spiculate tubercles; metanotum with similar, slightly smaller, spiculate paired tubercles (figs. 17, 18, 24); propodeum with median section spiculate. Tegula (figs. 17, 18, 25) with strongly projecting, large, nonspiculate tubercle, longer than basal diameter; forewing with outer surface irregular and with tubercle (fig. 26) less than one-quarter distance to wing apex. Male forecoxa without tubercles; ${ }^{4}$ foretrochanter with large apical tubercle; forefemur somewhat produced at base, nontuberculate; midand hind coxae and midtrochanter, each with moderately small, pointed, apical tubercle; hind trochanter with somewhat larger, pointed apical tubercle; hind tibia with large, projecting, spiculate tubercle on outer surface near base (fig. 27); other leg segments without unusual tubercles. Female leg tubercles about as described for male except hind trochanter with larger apical tubercle.

Metasoma: Integument without setae, spiculate in some dorsal areas and sterna more distinctly spiculate; T2-6 (male) or T2-5 (female) with posterior transverse row of moderately large, erect, mostly sharply pointed tubercles on each side; tubercles closest to midline tending to be largest; apex of metasoma with rounded median apical tubercle. Male S14 each with median rounded apical tubercle; male S5 with small apical projection medially

\footnotetext{
${ }^{4}$ Because of the small body size and the transparency of the pupal exoskeleton, the descriptions of the basal leg tubercles need to be verified with more recently preserved material.
}

but not rounded; shape of female S1 unknown; female S2-4 each with median projection.

Material Studied: Two male and two female pupae: Pakistan: Sind Province: Gharo, $38 \mathrm{mi}$ E of Karachi, May 8, 1984 (J.G. Rozen, S. Lodhi, I. Stupakoff).

\section{POSTDEFECATING LARVA OF CHIASMOGNATHUS PASHUPATI}

Figures 12-16

For comparative purposes, this description follows the format of a recently described larva of another nomadine bee (Rozen et al., 1997).

Diagnosis: The one feature whereby the mature larva of Chiasmognathus pashupati can be distinguished from those of all other known Nomadinae is the faint extension of the epistomal ridge mesad of each of the anterior tentorial pits on the cleared specimen, although the two sections of the ridge fade completely before meeting at the midline. At best, this ridge is difficult to see on such a small specimen. In all other respects the larva has all of the features of other Nomadinae, the monophyly of which is strongly supported by numerous other larval characters as given by Rozen (1996: 10-11). The larva closely resembles those of other known Ammobatini (Rozen and McGinley, 1974), but differs in that it possesses low but distinct paired tubercles on most body segments (fig. 12). Of all others it seems most similar to that of Ammobates carinatus Morawitz (ibid.: figs. 10-17), in that they share the following: greatly recessed labiomaxillary area, with the hypopharynx strongly projecting and its leading edge sharply projecting in lateral view (fig. 15); maxillary palpus very large, though not long (fig. 15); labroclypeal area large, strongly projecting in lateral view, extending well beyond other mouthparts (fig. 15); and mandible swollen at base so that base almost globose. (Contrary to the description in Rozen and McGinley, 1974, a reexamination of the mandible of $A$. carinatus revealed that it has very fine serrations on the dorsolateral and ventral apical edges, similar to but much finer than those of $C$. pashupati.) The similar appearing vertices as seen in lateral views (fig. 15; cf. Rozen and McGinley, 1974: 


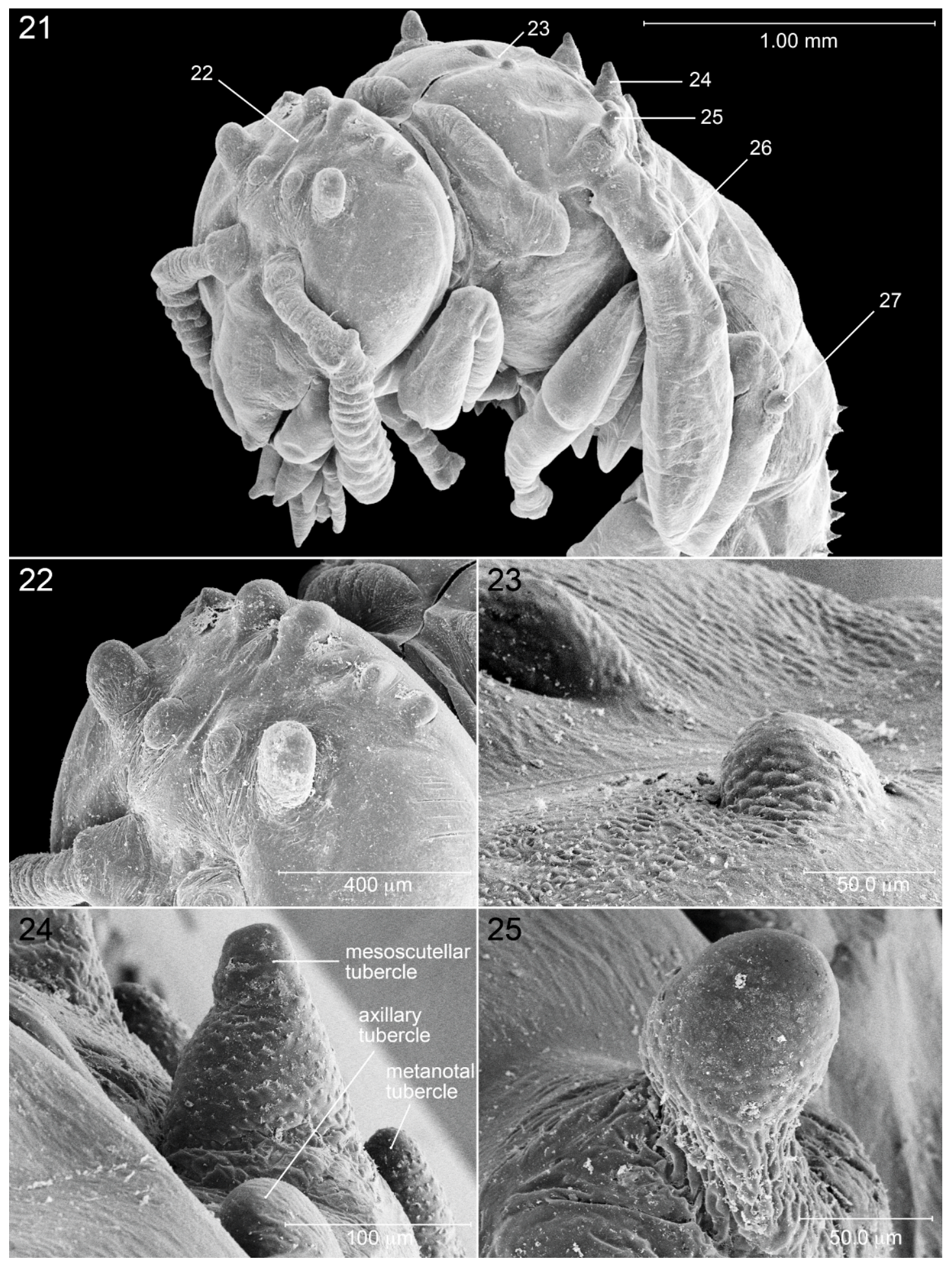

Figs. 21-25. SEM micrographs of pupa of Nomioides patruelis, approximate anterolateral view. 21. Anterior part of pupa with numbers referring to close-ups in figs. 22-25. 22. Close-up of frons and vertex. 23. Close-up of anterior mesoscutal tubercles. 24. Close-up of mesocutellar, axillary, and metanotal tubercles. 25. Close-up of tegular tubercle. 


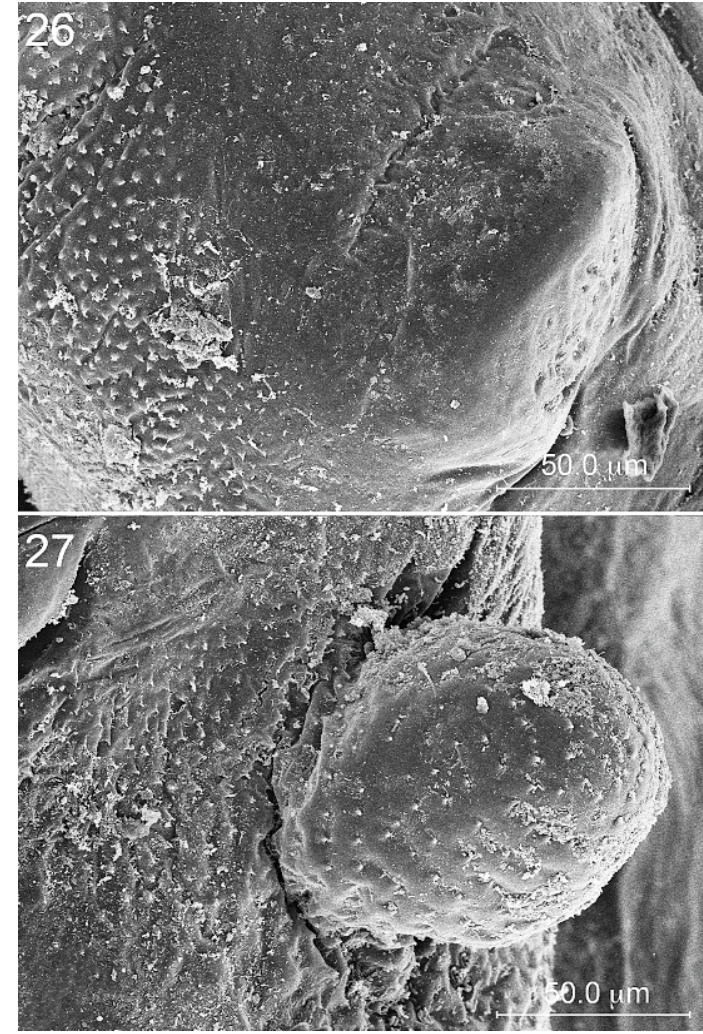

Figs 26-27. SEM micrographs of pupa of Nomioides patruelis, approximate anterolateral view. 26. Close-up of wing tubercle. 27. Close-up of hind-tibial tubercle.

fig. 17) may or may not be homologous; in $C$. pashupati the swelling extends across both parietals, whereas in A. carinatus it is restricted to the median and does not extend laterally.

DESCRIPTION: Length approximately 3.5 $\mathrm{mm}$. Head (figs. 14, 15): Unpigmented except for internal ridges, which are weakly pigmented; sensilla non-setiform; spiculation, including that of hypopharynx, absent.

Head size small compared with body; head capsule wider than long in frontal view; as seen in lateral view (fig. 12), parietals at top of head projecting forward on each side almost on level with vertex, well above antenna (see "Remarks" for discussion). Tentorium absent except at pits, presumably because specimen was about to molt (but presumably very thin as judged by remains of weak arms); anterior tentorial pit very small, apparently slightly closer to anterior mandibular articulation than to lower edge of antennal disc (but position of anterior mandibular articulation difficult to identify); posterior tentorial pit small, in front of cervical fold and posterior to curve of hypostomal ridge as ridge bends upward toward presumed junction with postoccipital ridge; postoccipital ridge not evident so that hypostomal ridge fading completely as its posterior end bends upward as if to meet postoccipital ridge; posterior margin of head capsule a faint line extending dorsolaterally to cervical fold (hence, same as second line as defined in Rozen et al., 1997; for further analysis of this feature in the Nomadinae, see Rozen, 1996: 6-7); integument in front of posterior margin sclerotized, nonspiculate, integument behind margin becoming conspicuously spiculate. Median longitudinal thickening of head capsule absent; hypostomal ridge moderately broad but weak; pleurostomal ridge weak, not clearly defined though moderately broad; epistomal ridge mesad of anterior tentorial pit broad but weak, extending diagonally upward immediately mesad of antennal disc before fading completely. Parietal band scarcely evident. Antennal prominence low, small; antenna positioned very low on face in frontal and lateral views (figs. 14, 15), perhaps in part because of exaggerated parietal above it; antennal disc and papilla not clearly differentiated; papilla bearing two sensilla. Labroclypeal region strongly projecting beyond frontal area with labrum large, without sclerite, with two sharply defined, apically acute, small tubercles; epipharynx a simple curved surface.

Mandible (fig. 16) (too small to be dissected from head but interpreted through cleared head capsule) short, robust (almost globular) at base, apically strongly curved toward mouth, and sharply pointed; cusp and apical concavity not differentiated, without denticles, outer surface with approximately five (possibly sensilla-bearing) scattered denticles; dorsal and ventral apical edges with conspicuous, sharply pointed, apically directed teeth. Maxilla strongly fused to labial region, its apex (except for palpus) small, surpassed by hypopharynx; galea and maxillary sclerites absent; palpus large at base, tapering rapidly to pointed apex, so that palpal length clearly shorter than basal diameter. Labium not 
divided into pre- and postmentum; premental sclerite absent; labial palpus presumably represented only by a sensillum somewhat posterior to salivary opening. Salivary opening simple, circular, without lips. Hypopharynx projecting compared with labium and maxilla, but much less so than labroclypeal area in lateral view (fig. 15); hypopharyngeal groove presumed to be faint line close to salivary opening in frontal view (fig. 14).

Body (figs. 12, 13): Without setae but with large spicules on prothorax and on venters of other thoracic segments; spicules becoming successively smaller on venters of following abdominal segments and absent on abdominal segment 8-10; integument without spines or sclerotized tubercles. Body form slender, elongate; intersegmental lines weakly incised between most body segments but becoming more deeply incised after abdominal segment 6; dorsolateral intrasegmental lines not evident; thoracic and abdominal segments 1-7 with paired dorsolateral tubercles, those of segment 8 much less obvious and those of segments 7; paired tubercles absent on segments 9, 10; all dorsolateral tubercles moderately low, conical (i.e., not transverse); venter of abdominal segment 9 not produced; segment 10 not bulging ventrally, attached centrally to 9; anus a transverse slit, apical on 10; perianal area with dorsolateral and ventral lips (fig. 13). Spiracles subequal and moderate in size, except those of abdominal segment 8 with width of atrium about one-half of that of other spiracles; spiracles projecting beyond body wall, apparently without rims; peritreme present, moderately wide; atrium globular; atrial wall without denticles or rings; primary spiracular open with collar; subatrium moderately short, with about 10 chambers. Sex characters unknown.

Material Studied: One postdefecating larva, Pakistan: Sind Province: Gharo, $38 \mathrm{mi}$ E of Karachi, May 8, 1984 (J.G. Rozen, S. Lodhi, I. Stupakoff) from Nomioides nest \#2.

REMARKS: The forward-projecting parietals of Chiasmognathus pashupati are probably not homologous with the paired swellings on the vertices of most larval Brachynomadini because the swelling of the latter are more localized and are faintly wrinkled. The swell- ings of the parietals of $C$. pashupati are not discrete, but rather the top of each parietal is forward projecting, and its surface is not wrinkled.

\section{PUPA OF \\ CHIASMOGNATHUS PASHUPATI}

Figures 19, 20, 28-31

Diagnosis: Because of the pair of long, "furry" tubercles rising from the top of the head (figs. 19-22), the pupa of this bee can immediately be distinguished from those of other Nomadinae (including other Ammobatini) currently known (see references in McGinley, 1989; Rozen, 1989, 1992, 1994, 1997a, 1997b, and 2000). The absence of sharply pointed, apically pigmented tubercles on the vertex and/or mesoscutum is also unusual compared with pupae of other Nomadinae, except for those of the Brachynomadini (see Rozen, 1994, 1997a). The densely spiculate pupal integument has not been noted in other Nomadinae, but this is the first SEM study of a pupa of any cleptoparasitic bee, no matter the family.

Among the Ammobatini, the pupae of only the Old World Ammobates carinatus and new world Oreopasites vanduzeei Cockerell and $O$. favreauae Rozen have been described before (Rozen and McGinley, 1974; Rozen, 1992). In addition to the characters discussed above, the pupa of Chiasmognathus pashupati can be distinguished by its smaller size, geographic distribution, and host preference. Chiasmognathus is strictly Old World, known only to attack nests of Nomioides (Engel, 2007), the only other known cleptoparasite of which is Sphecodes nomioidis Pesenko (Radchenko, 1980; Pesenko, 1979). The pupa of C. pashupati will not run successfully in the preliminary key to cleptoparasitic bee pupae (Rozen, 2000).

DESCRIPTION: Length $3.5 \mathrm{~mm}$. Head: Integument without setae, but many areas pale, velvety (a feature unknown for other bee pupae); when viewed with SEM, velvety appearance due to densely set spicules (fig. 29). Vertex without rounded mounds or tubercles except each side with erect, elongate, hornlike tubercle (figs. 19, 20, 28, 29), beset with microscopic spicules somewhat more elongate than spic- 

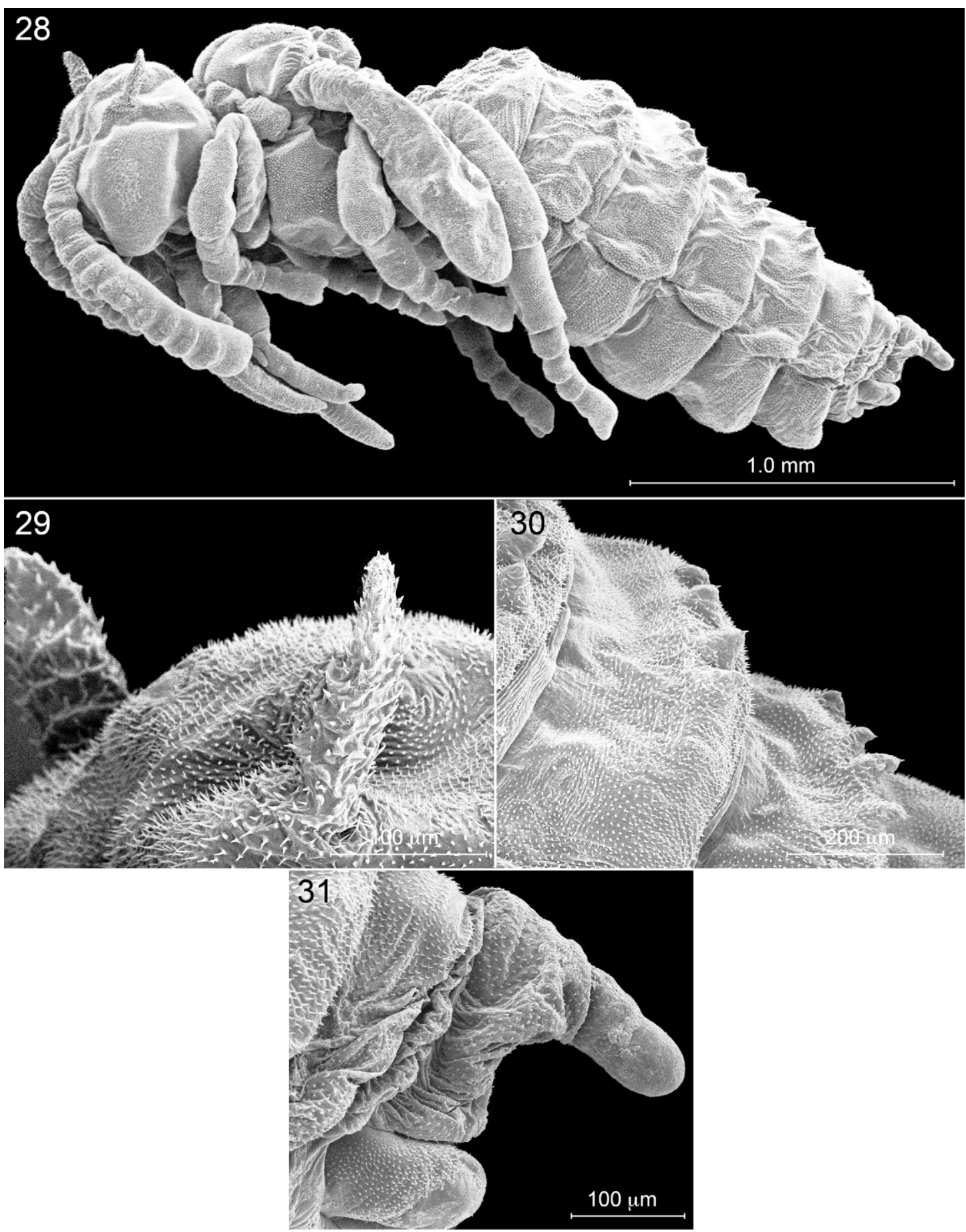

Figs 28-31. SEM micrographs of pupa of Chiasmognathus pashupati, approximate lateral views. 28. Entire pupa, showing broad distribution of dense spicules. 29. Close-up of left vertical tubercle; note left lateral, nonspiculate ocellus behind tubercle. 30. T3, T4 showing dense spiculation and row of sharply pointed tubercles at posterior margin of each. 31. Apex of metasoma showing widespread spiculation and nonspiculate terminal spine. 
ules elsewhere on head; these tubercles arising about midway between lateral ocelli and upper orbits; elsewhere head lacking tubercles; apex of clypeus with rounded, downward-projecting swelling on each side of labrum (these swellings referred to as tubercles by Rozen and McGinley, 1974, who recognized them as allowing for the development of the specialized hair tufts of adult males); pupal ocelli weakly defined. Labrum swollen medially, projecting in lateral view; as in adults with mouthparts folded, mandibles directed posteromedially, resting alongside labrum, not crossing labrum; mandibles vaguely swollen subapically, both adorally and medially.

Mesosoma: Integument covered in most areas with pale, dense, velvety, microscopic spiculation; setae absent. Posterior lobes of pronotum normal, not produced. Mesepisternum without tubercles; mesoscutum without rounded or sharp tubercles or even verrucae; axillae unmodified, not elevated; mesoscutellum with pair of paramedian, apically rounded, low but distinct tubercles (best seen in lateral profile); metanotum not pronounced. Tegula not produced, without tubercle(s); wings without tubercles but with a few irregular swellings. All coxae, trochanters, femora, tibiae, and tarsi without tubercles.

Metasoma: Integument covered in most areas with pale, velvety spiculation; setae absent. T1 with one or two small dorsolateral tubercles near posterior margin on each side; T2-T6 with submarginal row of three to four dorsolateral tubercles on each side; larger tubercles sharply pointed though apparently unpigmented; T7 without tubercle. Sterna without tubercles. Apex of metasoma produced as parallel-sided (when seen from above), apically rounded, nonspiculate terminal spine (fig. 31). Spiracles and anus unpigmented at time of preservation.

Material Studied: One male pupa, Pakistan: Sind Province: Gharo, $38 \mathrm{mi}$ E of Karachi, May 8, 1984 (J.G. Rozen) from nest of Nomioides patruelis. The specimen had obviously been preserved soon after it eclosed; there was no hint of pigmentation.

REMARKs: This pupa seems very unlike the known pupae [Oreopasites and Pasites (= Morgania)] of other Ammobatini (Rozen and
McGinley, 1974) because it lacks sharppointed vertical and mesoscutal tubercles. However, it agrees with these because of the presence of paired, downward-projecting swellings at the lower end of the clypeus next to the labrum (ibid.: fig. 29). The pale, velvety, dense spiculation covering most of the pupal integument of Chiasmognathus pashupati has not been noticed among other pupal Nomadinae (although future studies of these pupae should include SEM examination). Its function is uncertain as is the function of the paired, hornlike, vertical tubercles.

\section{ACKNOWLEDGMENTS}

I extend my thanks to the following individuals who accompanied $m e$ in Pakistan: Manzoor Ahmed, Rafiq Ahmad, S. Lodhi, R.J. McGinley, and I. Stupakoff. Funding for the fieldwork was provided by a grant to me from the Smithsonian Foreign Currency Program. Larval specimens from the University of California, Berkeley, were loaned by the late Paul D. Hurd; those from the University of Kansas were loaned by Charles D. Michener. Larval specimens at the Smithsonian Institution were loaned through the courtesy of David Furth, Brian Harris, and Molly G. Rightmyer.

Michael S. Engel identified and named the adults of Chiasmognathus pashupati, and Yuri Pesenko kindly identified specimens of Nomioides patruelis as did Pavel Klimov for the mites associated with the nesting site.

I extend my sincere thanks to Michael S. Engel and two outside reviewers for their suggestions on improving the manuscript.

\section{REFERENCES}

Alexander, B.A., and C.D. Michener. 1995. Phylogenetic studies of the families of shorttongued bees (Hymenoptera: Apoidea). University of Kansas Science Bulletin 55: 377-424.

Batra, S.W.T. 1966. Nests and social behavior of halictine bees of India (Hymenoptera: Halictidae). Indian Journal of Entomology 28: 375-393.

Blüthgen, P. 1925. Die Bienengattung Nomioides Schenck. Stettiner Entomologische Zeitung 86: $1-100$. 
Claude-Joseph, F. 1926. Recherches biologique sur les hyménoptères du Chile (mellifères). Annales des Sciences Naturelles, Zoologie 10: 114-268.

Eickwort, G.C. 1979. A new species of wooddwelling sweat bee in the genus Neocorynura, with description of its larva and pupa (Hymenoptera: Halictidae). Entomologia Generalis 5: 143-148.

Eickwort, G.C., and K.R. Eickwort. 1972a. Aspects of the biology of Costa Rican halictine bees, IV. Augochlora (Oxystoglossella) (Hymenoptera: Halictidae). Journal of the Kansas Entomological Society 45: 18-45.

Eickwort, G.C., and K.R. Eickwort. 1972b. Aspects of the biology of Costa Rican halictine bees, III. Sphecodes kathleenae, a social cleptoparasite of Dialictus umbripennis (Hymenoptera: Halictidae). Journal of the Kansas Entomological Society 45: 529-541.

Eickwort, G.C., and K.R. Eickwort. 1973. Aspects of the biology of Costa Rican halictine bees, V. Augochlorella edentata (Hymenoptera: Halictidae). Journal of the Kansas Entomological Society 46: 3-16.

Engel, M.S. 2007. A new species of Chiasmognathus from southeastern Pakistan (Hymenoptera: Apidae). Journal of the Kansas Entomological Society 80: 169-174.

Garófalo, C.A., and J.G. Rozen, Jr. 2001. Parasitic behavior of Exaerete smaragdina with descriptions of its mature oocyte and larval instars (Hymenoptera: Apidae: Euglossini). American Museum Novitates 3349: 1-26.

Hirashima, Y. 1961. Monographic study of the subfamily Nomiinae of Japan (Hymenoptera, Apoidea). Acta Hymenopterologica 1: 241-303.

McGinley, R.J. 1989. A catalog and review of immature Apoidea (Hymenoptera). Smithsonian Contributions to Zoology 494: 1-24.

Michener, C.D. 1953. Comparative morphology and systematics studies of bee larvae with a key to the families of hymenopterous larvae. University of Kansas Science Bulletin 35: 987-1102.

Michener, C.D. 2000. The bees of the world. Baltimore, MD: Johns Hopkins University Press, xiv $+[1]+913$ pp.

Pesenko, Y.A. 1979. A new species of the genus Sphecodes Latr. from the nest of Nomioides minutissimus (Rozzi) [sic] (HymenopteraHalictidae). Entomological Review 58: 136. [Original in Russian, in Entomologicheskoye Obozreniye, 1979.]

Pesenko, Y.A. 2000. Phylogeny and classification of the family Halictidae revised (Hymenoptera:
Apoidea). Journal of the Kansas Entomological Society 72(1999): 104-123.

Radchenko, V.G. 1980. The nesting of Nomioides minutissimus (Rossi) (Hymenoptera, Halictidae). Entomological Review 58: 71-74. [Original in Russian, in Entomologicheskoye Obozreniye, 1979.]

Rozen, J.G., Jr. 1965. The biology and immature stages of Melitturga clavicornis (Latreille) and of Sphecodes albilabris (Kirby) and the recognition of the Oxaeidae at the family level (Hymenoptera, Apoidea). American Museum Novitates 2224: 1-18.

Rozen, J.G., Jr. 1984. Comparative nesting biology of the bee tribe Exomalopsini (Apoidea: Anthophoridae). American Museum Novitates 2798: 1-37.

Rozen, J.G., Jr. 1986. The natural history of the Old World nomadine parasitic bee Pasites maculatus (Anthophoridae: Nomadinae) and its host Pseudapis diversipes (Halictidae: Nomiinae). American Museum Novitates 2861: 1-8.

Rozen, J.G., Jr. 1989. Two new species and the redescription of another species of the cleptoparasitic bee genus Triepeolus with notes on their immature stages (Anthophoridae: Nomadinae). American Museum Novitates 2956: 1-18.

Rozen, J.G., Jr. 1992. Systematics and host relationships of the cuckoo bee genus Oreopasites (Hymenoptera: Anthophoridae: Nomadinae). American Museum Novitates 3046: 1-56.

Rozen, J.G., Jr. 1994. Biology and immature stages of some cuckoo bees belonging to Brachynomadini, with descriptions of two new species (Hymenoptera: Apidae: Nomadinae). American Museum Novitates 3089: 1-23.

Rozen, J.G., Jr. 1996. Phylogenetic analysis of the cleptoparasitic bees belonging to the Nomadinae based on mature larvae (Apoidea: Apidae). American Museum Novitates 3180: $1-39$.

Rozen, J.G., Jr. 1997a. New taxa of brachynomadine bees (Apidae: Nomadinae). American Museum Novitates 3200: 1-26.

Rozen, J.G., Jr. 1997b. Pupal description of Neopasites cressoni (Apidae: Nomadinae: Biastini). Journal of the Kansas Entomological Society 70: 76-78.

Rozen, J.G., Jr. 2000. Pupal descriptions of some cleptoparasitic bees (Apidae), with a preliminary generic key to pupae of cleptoparasitic bees. American Museum Novitates 3289: 1-19.

Rozen, J.G., Jr., and R.J. McGinley. 1974. Systematics of ammobatine bees based on their mature larvae and pupae (Hymenoptera, 
Anthophoridae, Nomadinae). American Museum Novitates 2551: 1-16.

Rozen, J.G., Jr., and C.D. Michener. 1988. Nests and immature stages of the bee Paratetrapedia swainsonae (Hymenoptera: Anthophoridae). American Museum Novitates 2909: 1-13.

Rozen, J.G., Jr., and H. Özbek. 2003. Oocytes, eggs, and ovarioles of some long-tongued bees (Hymenoptera: Apoidea). Appendix: Parammobatodes rozeni, a new bee species from Israel, by M. Schwarz. American Museum Novitates 3393: 1-35.

Rozen, J.G., Jr., and H. Özbek. 2008. Immatures of rophitine bees, with notes on their nesting biology (Hymenoptera: Apoidea: Halictidae). American Museum Novitates 3609: 1-35.

Rozen, J.G., Jr., A. Roig-Alsina, and B.A. Alexander. 1997. The cleptoparasitic bee genus Rhopalolemma, with reference to other
Nomadinae (Apidae) and biology of its host Protodufourea (Halictidae: Rophitinae). American Museum Novitates 3194: 1-28.

Snelling, R.R., and G.I. Stage. 1995. Systematics and biology of the bee genus Xeralictus (Hymenoptera: Halictidae, Rophitinae). Natural History Museum of Los Angeles County Contributions in Science 451: $1-17$.

Torchio, P.F. 1975. The biology of Perdita nuda and descriptions of its immature forms and those of its Sphecodes parasite (Hymenoptera: Apoidea). Journal of the Kansas Entomological Society 48: 257-279.

Torchio, P.F., J.G. Rozen, Jr., G.E. Bohart, and M.S. Favreau. 1967. Biology of Dufourea and of its cleptoparasite, Neopasites (Hymenoptera: Apoidea). Journal of the New York Entomological Society 75: 132-146. 
Complete lists of all issues of the Novitates and the Bulletin are available at World Wide Web site http://library.amnh.org/pubs. Inquire about ordering printed copies via e-mail from scipubs@amnh.org or via standard mail from: American Museum of Natural History, Library-Scientific Publications, Central Park West at 79th St., New York, NY 10024. TEL: (212) 769-5545. FAX: (212) 769-5009.

అ) This paper meets the requirements of ANSI/NISO Z39.48-1992 (Permanence of Paper). 